\title{
Analysing Peatland Subsidence in Pelalawan Regency, Riau Using DInSAR Method
}

\author{
Ruli Dwi Susanti dan Ira Mutiara Anjasmara
}

\begin{abstract}
Indonesia is known as a country that have the largest peatland in Southeast Asia. Peatland is often used in agricultural, plantation and settlement purposes. Before, peatland must be drained as one procedure of land clearing activity. However, an error during this process often comes and cause some problems such as drought, subsidence and even forest fire. A characteristic of peatland, irrewetable, making peatland is very hard to be wet after getting dry. This research is aiming to observe peatland subsidence in Pelalawan Regency, Riau using SAR data Sentinel 1-A. The method that we use is Differential Interferometry Synthetic Aperture Radar (DInSAR). Beside Sentinel 1-A, DEM STRTM is used to remove topographic effect. Temporal baseline in this research is about one year between two acquisition data. The first pair of data is acquired in June 2015 and June 2016. While the second pair of data is acquired in June 2016 and July 2017. By using two pass DInSAR method, the process will yield two images of Line of Sight (LOS) Displacement during each period. The first DInSAR (June 2015-June 2016) reveals that the highest subsidence that occur in peatland is about 109,113 mm and the highest uplift is about 108,089 $\mathrm{mm}$. The second DInSAR (June 2016-July 2017) reveals that the highest peat subsidence is about 251,842 $\mathrm{mm}$ and the highest uplift is about 73,715 $\mathrm{mm}$.
\end{abstract}

Keywords-DInSAR, Synthetic Aperture Radar, Land Subsidence, Riau

\section{INTRODUCTION}

Indonesia is known as one a country with largest peatland covered in Southeast Asia. At least, Indonesia has 20,6 million hectare of peatland with $43 \%$ of them is in Sumatera [1]. Peatland is early defined as marginal land which is developed for agricultural, plantation and settlement purpose. Degradation and development of peatland areas is commonly connected with deforestation and drainage in the process of opening land up for agricultural purpose such as palm and pulp. Before opening land for cultivation, drainage must be done as a step of reclamation. Generally, peatland can absorb water up to 13 times of its volume. Drainage is aiming for arrange water concentration which is contained in peatland to be appropriate with plant needed. But, making drainage canal which mistaken sometimes can lead some problem and cause peatland becoming drought and making them lost their ability to save water again. Another environment problems like subsidence and forest fire will be faced if the condition become worse. Subsidence brings some negative impact for some plants such as rubber plantation, palm etc. Instead, if this condition could not be handed, water reservoir crisis will happen sooner or later. Pelalawan is one of regency in Riau

Ruli Dwi Susanti dan Ira Mutiara Anjasmara are with Department of Geomatics Engineering, Institut Teknologi Sepuluh Nopember, Surabaya, 60111, Indonesia. E-mail: ira@geodesy.its.ac.id.
Province which has peatland covering almost $50 \%$ of its area. Peatland in Pelalawan is managed for some purpose such as Conservation Forest, Industrial Forest and Food Corps Forest. Some problems such as forest fire that happened almost in every year since 2015 attempt to observe more about peatland condition. Peatland subsidence is one of several indicator to watch peatland degradation. Before, peatland subsidence is monitored by using PVC tubes as poles anchored into the substrate underlying the peat, or using Differential Global Positioning System [2].

Synthetic Aperture Radar (SAR) has ability to record data earth surface without depending on weather, fog, haze even night or afternoon. However, SAR imaged have sereve geometric distortion such as layover and shadow, which are the consequences of side looking viewing geometry and underlying topography relief [3]. Some study before used two different method in observing peatland subsidence. The first study used InSAR technology for analysing ALOS data in Sumatera while the other used Landsat 8 Imagery and GPS data for validation. Differential Interferometry Synthetic Aperture Radar (DInSAR) is developed after Interferometry SAR (InSAR) technology. Differential Interferometry is produced from two SAR data which are acquired in different time and in the same area [4]. The result of DInSAR processing is Line of Sight Imagery (LOS) which gives deformation values in every point represented by every pixel of SAR data.

\section{Methodology}

\section{A. Study Area and Data}

This study was performed at Pelalawan Regency, Riau Province $\left(00^{\circ} 48^{\prime} 32^{\prime \prime} \mathrm{N}-00^{\circ} 24^{\prime} 14^{\prime \prime S}\right.$ and 101 $30^{\prime} 40^{\prime \prime} \mathrm{E}$ $103^{\circ} 23^{\prime} 22^{\prime \prime}$ E). Located in the east coast of Sumatera, Pelalawan has high potential of peatland. Monitoring peatland using DInSAR method needs several data that can be downloaded easily such as Sentinel 1-A SLC Level 1.0 with VV polarisation and descending direction from https://vertex.daac.asf.alaska.edu/,orbital data and DEM SRTM 30m. Details data can be seen in the Table 1 and 2.

\section{B. Data Processing}

\section{Interferometry SAR Processing (InSAR).}

There are 2 important steps that must be passed, they are coregistration and Interferogram formatting. Coregistration attempt to align pixel between one SAR data to the other ${ }^{[3]}$. Interferogram formatting is used in flattening step to change projection field. This step produce coherence information between two imagery. Coherence indicates similiarity between a pair of SAR data. Coherence value is about $0-1$, the higher value of coherence gives better result. 
IPTEK Journal of Proceedings Series No. (2) (2019), ISSN (2354-6026)

The $3^{\text {rd }}$ Geomatics International Conference 2018

July $12^{\text {th }} 2018$, Institut Teknologi Sepuluh Nopember, Surabaya, Indonesia

TABLE 1.

SENTINEL 1-A DATA

\begin{tabular}{|c|c|}
\hline ID Scene & Tanggal \\
\hline 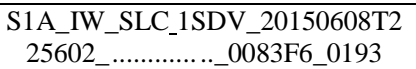 & 8-Juni-2015 \\
\hline $\begin{array}{c}\text { S1A_IW_SLC_1SDV_20160614T2 } \\
25609 \_\ldots \ldots \ldots \ldots . . . .011 F 49 \_36 A A\end{array}$ & 14-Juni-2016 \\
\hline $\begin{array}{c}\text { S1A_IW_SLC_1SDV_20150627T2 } \\
24756 \_\ldots \ldots \ldots \ldots . . .008 B D 1 \_B B 56\end{array}$ & 27-Juni-2015 \\
\hline $\begin{array}{c}\text { S1A_IW__SLC_1SDV_20160609T2 } \\
24803 \_\ldots \ldots \ldots \ldots . . . .011 C F 2 \_C 48 C\end{array}$ & 9-Juni 2016 \\
\hline $\begin{array}{c}\text { S1A_IW_SLC_1SDV_20170703T2 } \\
\text { 25603_..........._01CE81_D903 }\end{array}$ & 3-Juli-2017 \\
\hline $\begin{array}{c}\text { S1A_IW_SLC_1SDV_20160602T2 } \\
25623 \text { _.............0119CA_8579 }\end{array}$ & 2-Juni-2016 \\
\hline $\begin{array}{c}\text { S1A_IW_SLC_1SDV_20170703T2 } \\
25628 \_\ldots \ldots \ldots \ldots \ldots . .01 C E 81 \_8719\end{array}$ & 3-Juli-2017 \\
\hline S1A_IW_SLC_1SDV_20170710T2 & 10-Juli-2017 \\
\hline ID Scene & Level \\
\hline $\begin{array}{l}\text { S1A_IW_SLC_1SDV_20150608T2 } \\
\text { 25602_ .._0083F6_0193 }\end{array}$ & 1.0 (Single Look Complex) \\
\hline $\begin{array}{l}\text { S1A_IW_SLC_1SDV_20160614T2 } \\
25609 \quad . .1011 \mathrm{~F} 49 \text { 36AA }\end{array}$ & 1.0 (Single Look Complex) \\
\hline $\begin{array}{l}\text { S1A_IW_SLC_1SDV_20150627T2 } \\
24756 \_\quad . .008 \mathrm{BD} 1 \_B \mathrm{~B} 56\end{array}$ & 1.0 (Single Look Complex) \\
\hline $\begin{array}{l}\text { S1A_IW_SLC_1SDV_20160609T2 } \\
24803 \_\quad . .011 \mathrm{CF} 2 \text { C48C }\end{array}$ & 1.0 (Single Look Complex) \\
\hline $\begin{array}{l}\text { S1A_IW_SLC_1SDV_20170703T2 } \\
\text { 25603_ ...01CE81_D903 }\end{array}$ & 1.0 (Single Look Complex) \\
\hline $\begin{array}{l}\text { S1A_IW_SLC_1SDV_20160602T2 } \\
\text { 25623_ } \quad . .0119 C A \_8579\end{array}$ & 1.0 (Single Look Complex) \\
\hline $\begin{array}{l}\text { S1A_IW_SLC_1SDV_20170703T2 } \\
\text { 25628_ .._01CE81_8719 }\end{array}$ & 1.0 (Single Look Complex) \\
\hline $\begin{array}{l}\text { S1A_IW_SLC_1SDV_20170710T2 } \\
\text { 24806__.._01D18B_655B }\end{array}$ & 1.0 (Single Look Complex) \\
\hline $\begin{array}{c}\text { ID Scene } \\
\text { S1A_IW_SLC_1SDV_20150608T2 } \\
25602 \quad \text {.. } 0083 \mathrm{~F} 60193\end{array}$ & $\begin{array}{c}\text { Arah } \\
\text { Descending }\end{array}$ \\
\hline 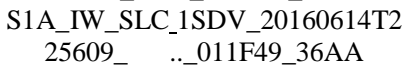 & Descending \\
\hline $\begin{array}{l}\text { S1A_IW_SLC_1SDV_20150627T2 } \\
\text { 24756__.._008BD1_BB56 }\end{array}$ & Descending \\
\hline $\begin{array}{l}\text { S1A_IW_SLC_1SDV_20160609T2 } \\
24803 \text { _.._011CF2_C48C }\end{array}$ & Descending \\
\hline $\begin{array}{l}\text { S1A_IW_SLC_1SDV_20170703T2 } \\
\text { 25603__.._01CE81_D903 }\end{array}$ & Descending \\
\hline $\begin{array}{l}\text { S1A_IW_SLC_1SDV_20160602T2 } \\
\text { 25623_ .._0119CA_8579 }\end{array}$ & Descending \\
\hline $\begin{array}{l}\text { S1A_IW_SLC_S1SDV_20170703T2 } \\
\text { 25628_ .._01CE81_8719 }\end{array}$ & Descending \\
\hline $\begin{array}{c}\text { S1A_IW_SLC_1SDV_20170710T2 } \\
24806 \text { _..01D18B_655B }\end{array}$ & Descending \\
\hline
\end{tabular}

2. Differential Interferometry SAR (DInSAR) Processing

Basically, this phase is divided into two phases, namely Phase Filtering and Topo Phase Removal. Phase filtering in the DInSAR process is used to increase the Signal to Noise Ratio (SNR) value that is still contained in the interferogram due to the return of the signal to the atmospheric air so that the noise and orbit effects can be eliminated ${ }^{[4]}$. The SNR value (Signal to Noise Ratio) can illustrate the signal strength associated with the heat. The heat gains occur due to amplification when propelling the return signal through the air or atmospheric medium ${ }^{[5]}$. Topo Phase Removal phase is used to remove topographic effects using the Digital Elevation Model (DEM) SRTM 30x30 m data.
TABLE 2.

PRECISE ORBITAL DATA [AUX_PEORB]

\begin{tabular}{cc} 
ID Scene & Tanggal \\
\hline \hline S1A_OPER_AUX_POEORB_OPOD_2015062 & \\
8T062238_V20150607T225944_2 & 8-Juni-2015 \\
0150609T005944 & \\
S1A_OPER_AUX_POEORB_OPOD_20160704T & \\
121657_V20160613T225943_2 & 14-Juni-2016 \\
0160615T005943 & \\
S1A_OPER_AUX_POEORB_OPOD_20150717T & \\
122248_V20150626T225944_2 & 27-Juni-2015 \\
0150628T005944 & \\
S1A_OPER_AUX_POEORB_OPOD_20160629T & \\
121538_V20160608T225943_2 & 9-Juni 2016 \\
0160610T005943 & \\
S1A_OPER_AUX_POEORB_OPOD_2017723T1 & 3-Juli-2017 \\
21520_V20170702T225942_20 170704T005942 & \\
S1A_OPER_AUX_POEORB_OPOD_20160622T & \\
121546_V20160601T225943_2 & 2-Juni-2016 \\
0160603T005943 & \\
S1A_OPER_AUX_POEORB_OPOD_20170723T & \\
121520_V20170702T225942_2 & 3-Juli-2017 \\
0170704T005942 & \\
S1A_OPER_AUX_POEORB_OPOD_20170730T & \\
121546_V20170709T225942_2 & 10-Juli-2017 \\
0170711T005942 & \\
\hline \hline &
\end{tabular}

\section{Phase Unwrapping}

This stage is performed to determine the absolute phase of the interferometric phase of the relative phase. The absolute phase has an interval value between $-\pi$ to $+\pi$ which must be converted into metric units to eliminate ambiguity.

4. Geocoding

The geocoding process is performed to transform the coordinates of the image from the radar coordinates (range / azimuth / height) to geographical coordinates.

Overlay

This process is done to paste DInSAR processing result with peatland distribution in Pelalawan Regency, Riau Province.

\section{RESUlT AND DISCUSSION}

\section{A. InSAR Processing Result.}

On InSAR processing stage, the phase value Interferometry will be generated with a range of values ranging from $0-2 \pi$. In addition, the value of coherence between master and slave image pairs is also obtained. In processing using this to pass method, two pairs of images are used with different time ranges. The first pair uses the June 2015 image as a master image and June 2016 image as a slave. The second pair uses the June 2016 image as a master image and image of June 2017 as a slave.

1) Coherence of interferogram

Correlation or coherence is the degree of similarity of the second phase of SAR imagery. Coherence value ranges starts from 0 to 1 , where the value 0 indicates no correlation at all and 1 represents the perfect correlation value. Coherence value itself is owned by every image pixel. In this study, 
coherence values are mostly found at intervals of 0.1 to $<0.2$. The frequency distribution of the coherence value of each pair of imagery can be seen in the following graph:

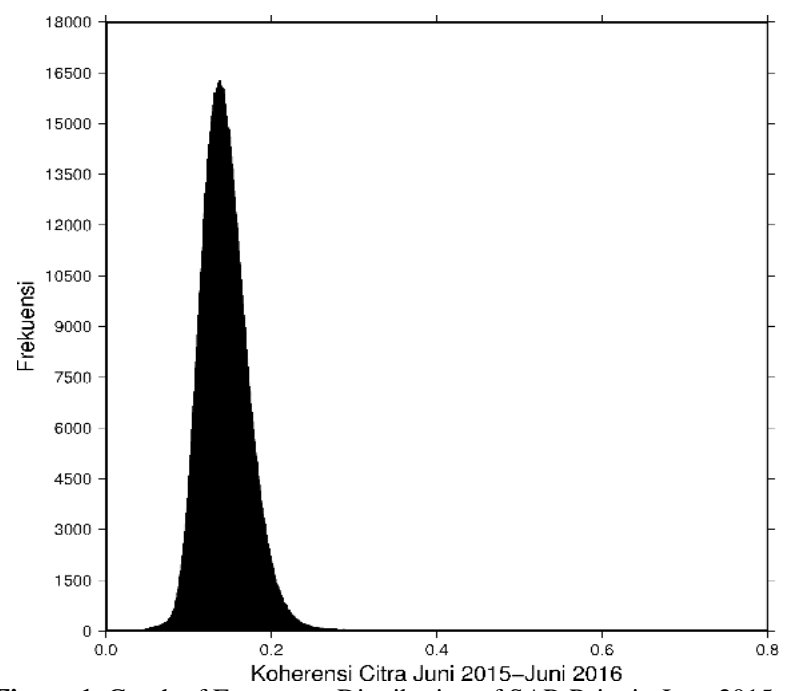

Figure 1. Graph of Frequency Distribution of SAR Pairs in June 2015 to June 2016.

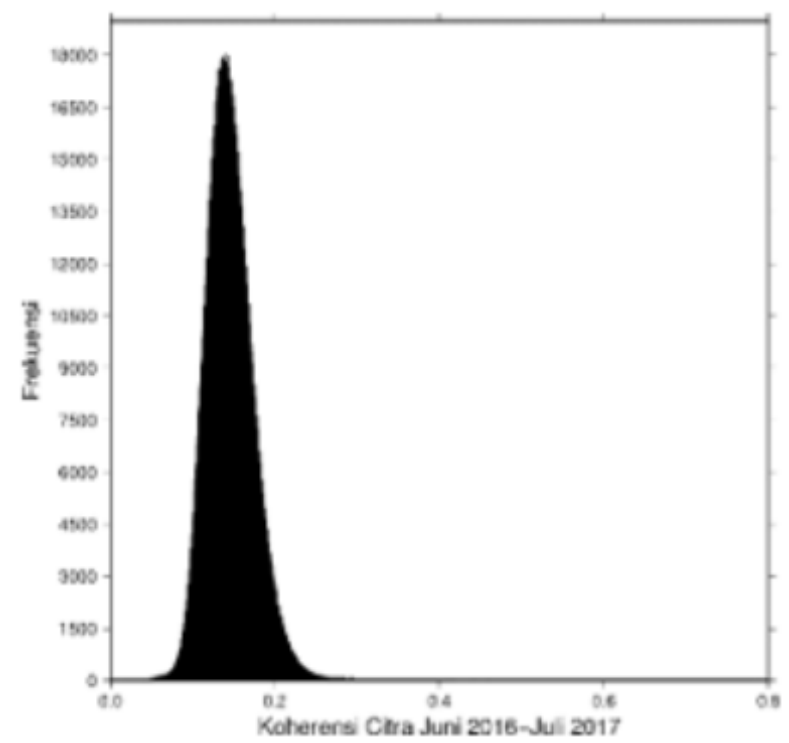

Figure 2. Graph of Frequency Distribution of SAR Pairs in June 2016 to July 2017.

The high coherence value (>0.2) is ideal in describing the real phase information. While the correlation value less than 0.1 gives the value of the less good phase. The absence of correlation value is also called the deccorelation that can occur between two pairs of SAR images with different times acquisition. The low value of coherence can be caused by several factors such as strength difference and dispersion distribution commonly called temporal deccorelation. The variables that influenced were crop growth, weather and recording interval. In addition, other factors that can make coherence value getting worse are spatial decorations that may occur due to the influence of spatial baselines (the distance between two orbits), and the volume of scattering
[2]. Based on previous research using InSAR technology [2], low coherence value $(<0.2)$ is indicated by areas with high vegetation density (forest) [5]. Low coherence shown in peat areas can be caused by the length of time interval. This is because plants (peat) tend to have a rapid growth and the change of environmental parameters.

TABLE 3.

BASELINE INFORMATION OF SAR PAIRS IN JUNE 2015 TO JUNE 2016

\begin{tabular}{|c|c|c|c|}
\hline ID Scene & $\begin{array}{l}\text { Time } \\
\text { Interval }\end{array}$ & IW & $\begin{array}{l}\text { Baseline } \\
\text { Distance }\end{array}$ \\
\hline $\begin{array}{r}\text { S1A_IW_SLC } \\
\text { 1SDV_20150608T225602_ }\end{array}$ & \multirow{3}{*}{$\begin{array}{l}366 \\
\text { hari }\end{array}$} & \multirow{3}{*}{1} & \multirow{3}{*}{$\begin{array}{c}45,333 \\
\mathrm{~m}\end{array}$} \\
\hline $\begin{array}{r}. .0083 F 6 \_0193 \\
\text { S1A_IW_SLC } \\
\text { 1SDV_20160614T225609_ }\end{array}$ & & & \\
\hline $\begin{array}{c}. .011 F 49 \_36 A A \\
\text { S1A_IW_SLC } \\
\text { 1SDV_20150627T224756_ }\end{array}$ & & & \\
\hline $\begin{array}{c}\text {..008BD1_BB56 } \\
\text { S1A_IW_SLC } \\
\text { 1SDV_20160609T224803_ }\end{array}$ & $\begin{array}{l}342 \\
\text { hari }\end{array}$ & \multirow[t]{2}{*}{3} & \multirow[t]{2}{*}{$\begin{array}{c}118,635 \\
\mathrm{~m}\end{array}$} \\
\hline ..011CF2_C48C & & & \\
\hline
\end{tabular}

TABLE 4.

BASELINE INFORMATION OF SAR PAIRS IN JUNE 2016 TO JULY 2017

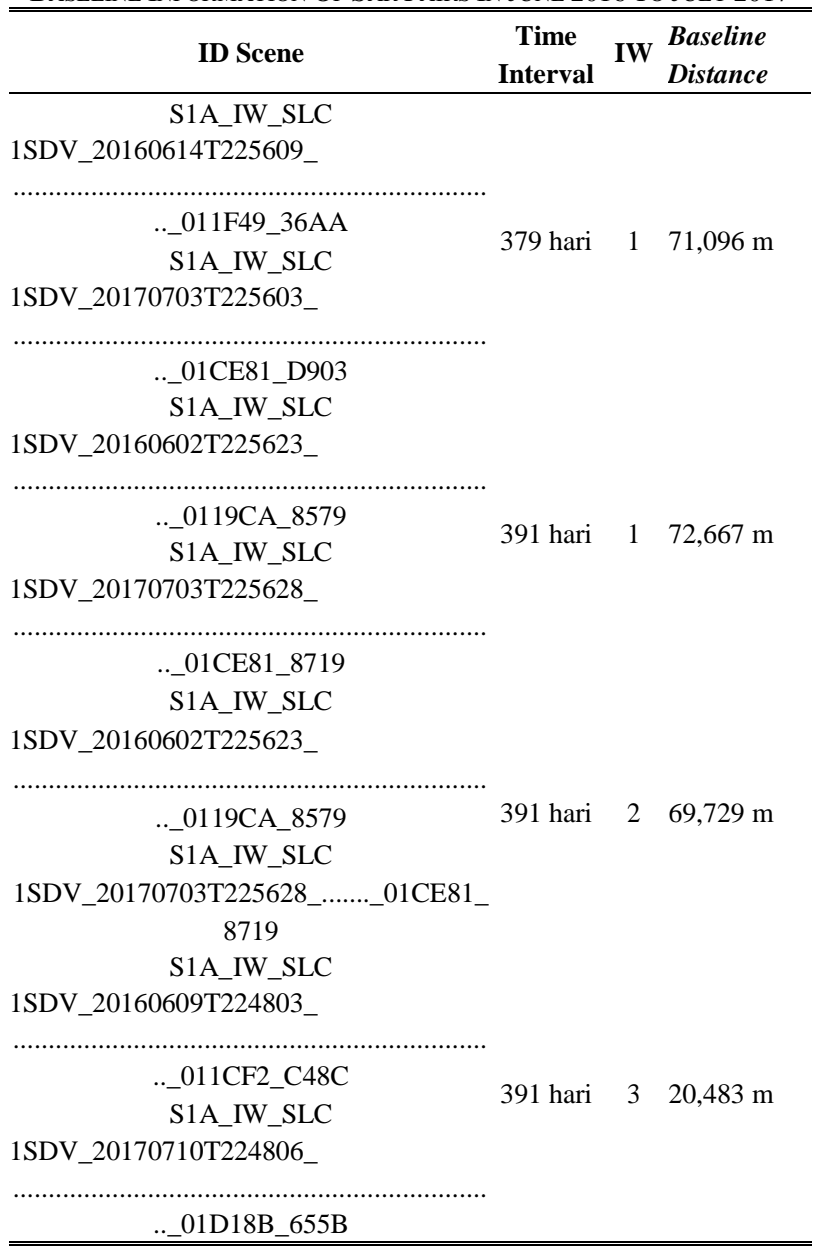


From the baseline processing result, the largest baseline distance is $118,635 \mathrm{~m}$ and the highest temporal distance is 391 days. The baseline distance is still relatively good, given that the maximum baseline distance for SAR data processing is $500 \mathrm{~m}$.

\section{B. Effects of Wavelenght Sensor and Atmospheric Conditions}

The wavelength of Sentinel 1-A (C-band) sensor is low compared to L-Band sensor. This resulted in C-Band Image tends to be more difficult to apply in areas with high vegetation (rural area) [6]. Sentinel- 1A (C-band) images have the inherent properties of penetrating the tree so that the signal is reflected back from the top of the tree canopy and only a few signals are reflected from the trunk [2]. The atmospheric conditions of the research area that is the equatorial region greatly affect the existence of noise and orbit effects that can cause a decrease in the quality of SAR data that affects the difficulty of the unwrapping process performed. The presence of noise in the interferogram image can be caused by the temperature, overlay or non-conformity system during the overlap process [4]. In the results data in the form of interferogram, image pairs in the study area did not show any significant changes in the form of fringes. This indicates that no significant change occurs due to a deformation phenomenon as is commonly shown in volcanic eruption phenomena, as well as earthquakes.

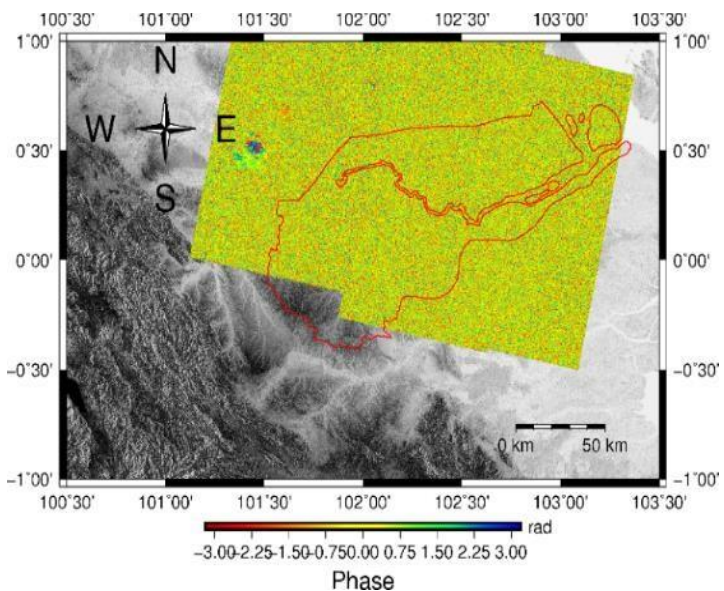

Figure 3. Interferometry image phase June 2015- June 2016.

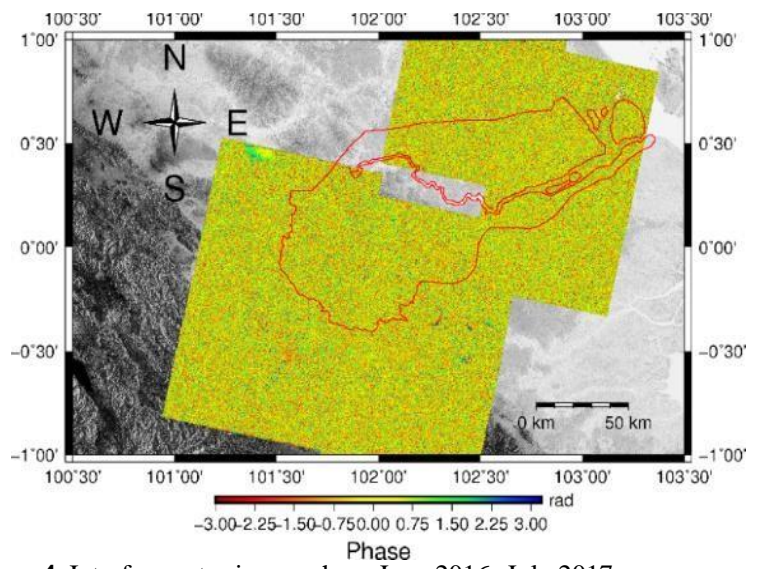

Figure 4. Interferometry image phase June 2016- July 2017.
C. Differential Interferometry SAR Processing Result

1) Pairs of Image in June 2015 - June 2016

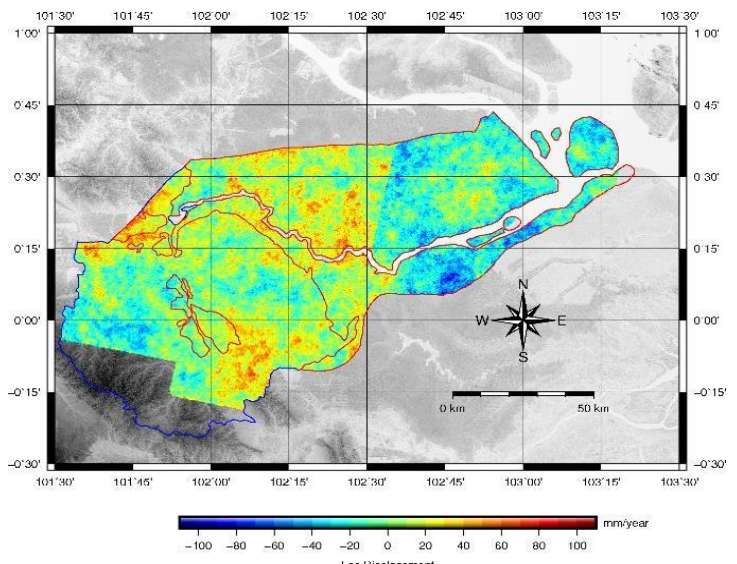

Figure 5. Line of Sight (LOS) Displacement June 2015 - June 2016.

From the results of the image processing of Sentinel 1-A using DInSAR method in June 2015 and June 2016, it was found that on the peat area there was an uplift with the highest value about $108,089 \mathrm{~mm}$ and the highest subsidence is about $109,113 \mathrm{~mm}$.

2) Pairs of Image in June 2016 - Jult 2017

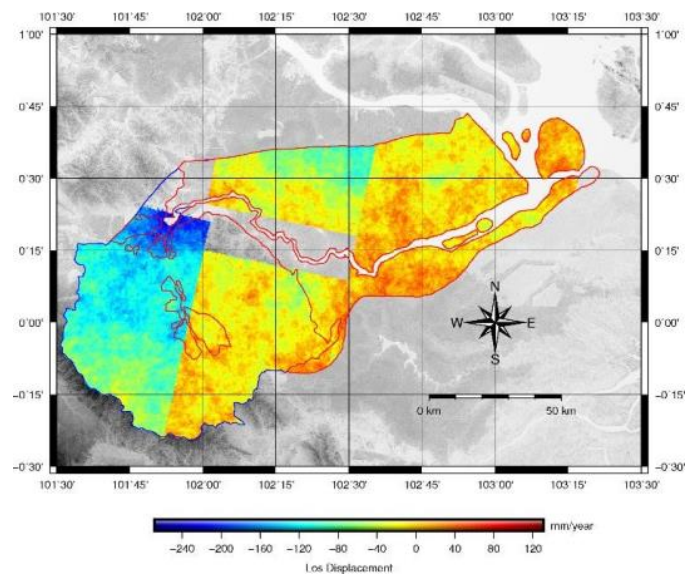

Figure 6. Line of Sight (LOS) Displacement June 2016 - July 2017.

From the results of the image processing of Sentinel 1-A using DInSAR method in June 2015 and June 2016, it was found that on the peat area there was an uplift wiht the highest value about $73,715 \mathrm{~mm}$ and the highest subsidence is about $251,842 \mathrm{~mm}$. The irregularity of deformation patterns in the form of uplift and subsidence can be caused by noise influenced by atmospheric conditions and even temporal decorations occurring in areas with high vegetation density, as well as forest fire phenomena occurring in June 2016 and July 2017 so the temperature increases.

\section{CONCLUSION}

Peat area in Pelalawan Regency, Riau is relatively uplift based on image processing in June 2015 and June 2016 and decreased (subsidence) based on image processing in June 
2016 and July 2017. The highest value of peat uplift according to DInSAR result pairs in June 2015-June 2016 is about $108,089 \mathrm{~mm}$ and the highest subsidence is about $109,113 \mathrm{~mm}$. 4. The results of the processing indicated that each pair of SAR imagery was influenced by the temporal deccorelation effects arising from peat growth rate, forest fires phenomenon and the high level of data acquisition time ranging from 342 to 391 days.

\section{ACKNOWLEDGEMENT}

Author thanks to squad of Geodynamics Laboratory-ITS for the support of facilities and guidance during this research.

\section{REFERENCES}

Turmudi and et al, "Pengelolaan Lahan Gambut dan Dampak
July $12^{\text {th }} 2018$, Institut Teknologi Sepuluh Nopember, Surabaya, Indonesia

Subsiden yang Ditimbulkannya (Studi Kasus Kepulauan Meranti, Provinsi Riau)," Bogor, 2016.

[2] Z. Zhou, "The Application Of InSAR Time Series Analysis for Monitoring Long-term Surface Change in Peatlands," United Kingdom, 2016.

[3] J. Zhang, J. Wei, G. Huang, and Y. Zhang, "Fusion of ascending and descending polarimetric sar data for colour orthophoto generation."

[4] X. Qing, J. Guowang, Z. Caiying, W. Zhengde, H. Yu, and Y. Peizhang, "The Filtering And Phase Unwrapping Of Interferogram."

[5] S. Samsonov and K. Tiampo, "Polarization Phase Difference Analysis for Selection of Persistent Scatterers in SAR Interferometry," IEEE Geosci. Remote Sens. Lett., vol. 8, no. 2, pp. 331-335, Mar. 2011

[6] S. Taekuchi and et al, "Comparison of InSAR Capability for Land Subsidence Detection between C- Band and L-Band SAR," Hiroshima, 2002. 